Review

\title{
Biofilm formation by Salmonella sp. in the poultry industry: Detection, control and eradication strategies
}

\author{
Lina Merino $^{\mathrm{a}, \mathrm{b}}$, Francisco Procura ${ }^{\mathrm{a}, \mathrm{c}}$, Fernando M. Trejo ${ }^{\mathrm{b}}$, Dante J. Bueno ${ }^{\mathrm{c}}$, \\ Marina A. Golowczyc ${ }^{\mathrm{b}, *}$ \\ ${ }^{\text {a }}$ Consejo Nacional de Investigaciones Científicas y Técnicas (CONICET), Argentina

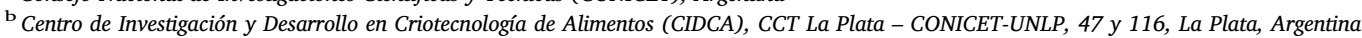 \\ ${ }^{\mathrm{c}}$ Instituto Nacional de Tecnología Agropecuaria EEA Concepción del Uruguay, Ruta Provincial $39 \mathrm{Km}$ 143,5, 3260 Concepción del Uruguay, Entre Ríos, Argentina
}

\section{A R T I C L E I N F O}

\section{Keywords:}

Salmonella

Biofilm

Poultry industry

Contamination control

\begin{abstract}
A B S T R A C T
Salmonella represents an important global public health problem and it is an emerging zoonotic bacterial threat in the poultry industry. Diverse registered human cases of salmonellosis shown poultry origins. Various control measures have been employed both at the farming and processing levels to address it. This review focuses on traditional and new detection techniques of biofilm formation by Salmonella spp. and different approaches that can be used to prevent and/or control biofilm formation by these bacteria. A number of methodologies based on different approximations have been recently employed to detect and evaluate bacteria attached to surfaces, including real-time polymerase chain reaction (PCR), confocal laser scanning microscopy and Optical Coherence Tomography. Due to persistence of Salmonella biofilm in food processing environments after cleaning and sanitation, control and eradication strategies in poultry industry should be constantly studied. In this sense, the use of several alternatives to control Salmonella biofilm formation, such as lactic acid bacteria, phagetherapy, extracts from aromatic plants, quorum sensing inhibitors, bacteriocins and nanomaterials, have been successfully tested and will be reviewed.
\end{abstract}

\section{Introduction}

Chicken meat and eggs are the best source of high quality protein, and are much needed by the many millions of people living in poverty (Farrell, 2013). The increase in meat consumption over the past decade has been driven mainly by the poultry meat sector, which represented two-thirds of the additional meat consumed. Poultry will account for the largest share of growth of meat consumed over the next decade to 2025 (Conway, 2016a). On the other hand, world egg production hit a significant milestone in 2015, when it reached more than 70 million metric tons for the first time in its history, the equivalent of 1338 billion eggs. The increase in world egg production between 2000 and 2015 was $38.7 \%$, an average rate of $2.2 \%$ per year (Conway, 2016b).

The marked increase in poultry meat and egg production can be affected by contamination caused by different microorganisms that produce biofilms. For most of the history of microbiology, microorganisms have primarily been characterized as planktonic, freely suspended cells and described on the basis of their growth characteristics in nutritionally rich culture media. The discovery of a microbiologic phenomenon, first described by van Leeuwenhoek, that microorganisms attach to and grow universally on exposed surfaces led to studies that revealed surface-associated microorganisms (biofilms) exhibited a distinctive phenotype with respect to gene transcription and growth rate. These biofilm microorganisms have been shown to elicit specific mechanisms for initial attachment to a surface, development of a community structure and ecosystem, and detachment (Donlan, 2002).

Furthermore, biofilms are becoming one of the buzzwords of the food industry. Various definitions exist but biofilm is an assemblage of microbial cells that is irreversibly attached (not removed by gentle rinsing) to a surface and enclosed in a matrix of primarily polysaccharide material. Non cellular materials such as mineral crystals, corrosion particles, clay or silt particles, or blood components, depending on the environment in which the biofilm has developed, may also be found in the biofilm matrix. Biofilm-associated organisms also differ from their planktonic counterparts with respect to the genes that are transcribed. Biofilms in nature usually persist attached to some surface and not as pure cultures of unattached. In this context, bacterial cells in a biofilm have the ability to exchange genetic components at an increased rate and this may facilitate the acquisition of new genes for virulence and environmental survival (Donlan, 2002; Giaouris et al.,

\footnotetext{
* Corresponding author at: (CIDCA), Universidad Nacional de La Plata, Calle 47 y 116, 1900 La Plata, Argentina.

E-mail addresses: marinagolowczyc@biol.unlp.edu.ar, mgolowczyc@yahoo.com.ar (M.A. Golowczyc).
} 
2015).

Bacterial cells often appear to be more resistant to against physical and chemical agents in a biofilm. The cleaning process can influence the 'food source' left on a surface and this, in turn, can influence the bacterial flora on that surface. In addition, it is suspected that bacteria in the film 'communicate' with each other by releasing specific chemicals. As the bacteria population increases, the concentration of these chemicals increases in their micro-environment and, at a certain concentration, specific genes in bacteria are turned on or off (Anonymous, 2008).

Removing the biofilm becomes more difficult due to its interaction with the chemical components of food (carbohydrates, fats, proteins, salts and even spices). Cleaning is the main way to control biofilms but, unfortunately, many of the cleaning compounds used in the food sector are not primarily designed to remove biofilms (Anonymous, 2008).

Salmonella (of the family Enterobacteriaceae) is a genus of rodshaped (bacillus) gram-negative bacteria that represents an important global public health problem, causing substantial morbidity, and thus also has a significant economic impact (Sharma \& Carlson, 2000). It consists of more than 2500 serologically distinguishable variants (or serotypes) that are frequently named for the place of initial isolation. In poultry, the numerous motile and non-host-adapted Salmonella serotypes, referred as paratyphoid Salmonella, are found nearly ubiquitously in wild and domestic animals. This diverse group of serotypes is principally of concern as a cause of food-borne disease in humans (Gast, 2008). The distribution of Salmonella serotypes from poultry sources varies geographically and changes over time, although several serotypes are consistently found at a high incidence (Gast, 2013). Contamination with this bacteria in poultry meat/eggs and poultry products can occur at multiple stages along the food chain, which includes production, processing, distribution, retail marketing, handling and cooking (Dookeran, Baccus-Taylor, Akingbala, Tameru, \& Lammerding, 2012). The modernization of poultry farms and globalization of the bird breeding trade have also played a key role spreading the infection (Velge, Cloeckeart, \& Barrow, 2005).

Salmonella adhesion to food surfaces was the first phenomena reported and published on foodborne bacterial biofilm (Duguid, Anderson, \& Campbell, 1966). Studies have found that bacterial cell surface components such as cellulose, flagella and fimbriae are important for the attachment of Salmonella to different surfaces (Kroupitski et al., 2009).Biofilms may play a crucial role in the survival of Salmonella under unfavorable environmental conditions, such as poultry farms and chicken slaughterhouses (Wang et al., 2013). Approximately, $50 \%$ of the Salmonella strains isolated on poultry farms were able to produce biofilms (Marin, Hernandez, \& Lainez, 2009). This bacteria can form biofilms on produced food, and also in processing areas of poultry farms such as walls, floors, pipes, and drains, and in contact surfaces, such as stainless steel, aluminum, nylon, rubber, plastic, polystyrene, and glass (Schonewille, Windhorst, \& Bräuni, 2012; Wang et al., 2013).

The poultry industry is intensive and consistently applies an all-in, all-out system with the aim of minimizing infection pressure and targeting specific organisms like Salmonella. Therefore, disinfecting during production break is a routine part of the management of poultry houses. Several chemical agents are commercially available for the elimination of Salmonella. However, different studies showed high prevalence of Salmonella in environment samples after cleansing and disinfecting in broilers and laying hen houses, proving that disinfection was ineffective against the bacteria in a field situation (Davies \& Breslin, 2003; Rose et al., 2000).

Despite the possibilities of combating Salmonella spp., it is important to understand that the biofilm-building property is a function of adaptation to the host's environment. Since biofilm can also form a habitat for Salmonella in farm environments and not only in laboratory conditions, its control is of paramount importance to the overall improvement of food safety. Early detection and management of potentially pathogenic Salmonella spp. is an essential step toward prevention and management of salmonellosis (Peng et al., 2016). Furthermore, special attention must be paid to environments that are notoriously difficult to decontaminate, for example, feed mills and primary poultry production (Schonewille et al., 2012).

In this review, we focus on traditional and new detection techniques of biofilm formation by Salmonella spp., which are important in poultry industry. Moreover, we present approaches that can be used to not only prevent but also control biofilm formation by these bacteria.

\section{The detection and quantification methods of microorganisms in biofilms}

Numerous methodologies based on different approximations have been developed for the phenotypic and genotypic detection and analysis of biofilm formation by microorganisms. These techniques aim to evaluate viability (quantification of viable cells), components of extra polymeric matrix (specific detection of extra polymeric substances, EPS) or biomass (evaluation of EPS and bacteria, both alive and dead).

\subsection{Phenotypic identification of biofilm-producing strains}

Three methods broadly used for the phenotypic identification of biofilm-producing strains are the test tube method (Karaca, Akcelik, \& Akcelik, 2013), the microtitre-plate test (MtP; Christensen et al., 1985) and the Congo red agar (CRA) test (Freeman, Falkiner, \& Keane, 1989). The first is a qualitative method, which studies the biofilm formation in a glass tube without staining. The pellicle is a biofilm structure that is observed in a liquid air interface. The strains are visually examined every day and classified according to their formation of a pellicle structure, the physical differences of the pellicle and any changes in the media related to pellicle formation (Solano et al., 2002).

The MtP was developed to replace the test tube method, which was the first method used for macroscopic estimation of bacterial biofilm on the surface of plastic tubes. The microtitre-plate technique uses a 96well-plate spectrophotometer to measure the optical density (O.D.) of stained bacterial biofilms found on the bottom of tissue culture plates and produces quantitative results of total biofilm, without distinguishing dead and alive cells. The adherent biofilms are stained with crystal violet. This is a basic protein dye that stains negatively charged surface molecules and extracellular matrix of polysaccharides from both EPS on viable and dead cells (Pitts, Hamilton, Zelver, \& Stewart, 2003). This staining has been shown to be a simple, fast and cheap technique to routinely study the biofilm formation. However, the principal disadvantage is its low replicability, mostly due to the detachment and removal of biomass during washing steps seeking to eliminate cells and dye not bonded to the biofilm (Gómez-Suárez, Busscher, \& van der Mei, 2001). This loss of biomass can be reduced by fixations using absolute ethanol, methanol or heating $\left(1 \mathrm{~h}\right.$ at $\left.60{ }^{\circ} \mathrm{C}\right)$ before staining (Stepanović et al., 2007).

The CRA plate test uses a solid medium, namely Congo red agar. This is not a quantitative assay because it is based on a subjective chromatic evaluation. This method allows for the direct analysis of the colonies and the identification of slime (exopolysaccharides)-forming strains (which appear as black colonies on the red agar with a dry crystalline consistency) and non-slime-forming strains (pink-colored colonies, occasional darkening at the center). An indeterminate result was indicated by a darkening of the colonies but with the absence of a dry crystalline colonial morphology (Freeman et al., 1989). A modification of this method, adding Coomassie brillant blue, permits to determine 5 biofilm morphotypes for each strain according to morphological colony characteristics (Karaca et al., 2013; Malcova, Hradecka, Karpiskova, \& Rychlik, 2008). These morphotypes are: (i) rdar (red, dry and rough; indicating curli fimbriae and cellulose); (ii) bdar (brown, dry and rough; indicating only curli fimbriae); (iii) pdar (pink, dry and rough; indicating only cellulose); (iv) sbam (smooth, 
brown, and mucoid; lack of cellulose synthesis, but overproduced capsular polysaccharide); (v) saw (smooth and white; indicating neither cellulose nor fimbriae). The rdar morphotype is the best characterized biofilm state, coordinating multicellular behavior and provide a survival advantage through enhanced resistance to desiccation and disinfection (White, Gibson, Kim, Kay, \& Surette, 2006).

The colony count enumeration method (CCEM) is the most extensively used technique to evaluate live cells and is based on the ability of bacteria to initiate cell division and form colonies on agar media (Donlan \& Costerton, 2002). However, this technique presents certain limitations: 1) fractions of cells detached from the biofilm to make numeration might not be representative of viable cells in the biofilm and 2) environmental stress may induce a viable-but-non-culturable state (VBNCS) on the bacteria, due to alterations on its metabolism (Shen, Stojicic, Qian, Olsen, \& Haapasalo, 2010). The metabolic activity of cells (MCs) has been used as a quantitative indirect measure of biofilm formation. Through respiratory chain enzymes, active cells are capable of reducing certain chemicals substances and producing changes on optical properties easily detected by spectrophotometry (Riss et al., 2004).

The most used substrate to evaluate biofilm formation is tetrazolium salts as 2,3-Bis-(2-Methoxy-4-Nitro-5-Sulfophenyl)-2H-Tetrazolium-5Carboxanilide (XTT). The XTT is reduced to formazan, a purple dye soluble in water which concentration on solution is directly proportional to the quantity of metabolically active cells (Roehm, Rodgers, Hatfield, \& Glasebrook, 1991; Xu et al., 2016).

Other colorimetric assay used is based on resazurin (Ahmed, Gogal, \& Walsh, 1994), which is reduced to resorufin (color pink), a fluorescent substance (Alamar Blue, color blue). This makes it possible to evaluate resazurin levels by mean spectrophotometry or spectrofluorometry, which increases sensibility (Peeters, Nelis, \& Coenye, 2008). Both, XTT and resazurin techniques have shown similar responses to those of planktonic cells with detection linear range $\sim 10^{5}-10^{8} \mathrm{CFU} /$ well (Peeters et al., 2008). As these techniques present a good correlation with the CCEM method, they could also be used to evaluate anti-biofilm effects by different treatments (Field, O'Connor, Cotter, Ross, \& Hill, 2016; Hu et al., 2017). The addition of resazurin in fresh media on mature biofilm has reduced the detection limit to $1000 \mathrm{CFU} /$ biofilm with a good correlation with CCEM method (Van den Driessche, Rigole, Brackman, \& Coenye, 2014).

Different microscopy techniques for the visualization and study of biofilms are used. The Confocal Laser Scanning Microscopy (CLSM) is probably the most widely used fluorescence microscopy to study biofilm, which allows evaluating spatial structure of biofilm and visualizing cell distribution on biofilm matrix (Neu \& Lawrence, 2014). CLSM is capable of acquiring planes of fluorescence at different depths on the biofilm, integrating these planes in a 3D image and obtaining parameters such as biofilm bio-volumen, thickness and roughness (Bridier, Dubois-Brissonnet, Boubetra, Thomas, \& Briandet, 2010). To visualize components of EPS by CLSM: 1) carbohydrates can be stained using lectins labelled with fluorocroms to detect glycoconjugates within the biofilm, where the patrons of stains obtained depend on the specificity of the lectins utilized; 2) proteins present can be stained using SUPRO red, and 3) eDNA can be stained using TOTO1. The combination of these techniques with those described before to bacterial staining, represents an interesting tool to study the biofilm architecture and organization of bacteria and the EPS components participating in the formation of the biofilm (Dominiak, Nielsen, \& Nielsen, 2011).

Scanning electron microscopy (SEM) is based on surface scattering and absorption of electrons achieving high depth yielding a 3-D appearance, and allows the visualization special of the biofilm and to know the distribution of bacteria and EPS dispersed on biofilms (Clayborn, Adams, Baker, \& Ricke, 2015). SEM has been used to study the ability of bacteria to develop biofilms on different substrates and several environmental conditions (De Oliveira et al., 2014; Pande, McWhorter, \& Chousalkar, 2016). It allows the quantification of area, volume and thickness of the biofilm (Azeredo et al., 2017) with a high resolution (50 to $100 \mathrm{~nm}$ ) and depth of field with a wide range of magnifications (20 to $30,000 \times$ ). Atomic force microscopy (AFM) is a characterization tool that measures the topology and material properties of surfaces by recording the deflection of a metallic "tip" as it moves over the target surface (Ozkan, Topal, Dana, Guler, \& Tekinay, 2016). The non-invasive AFM technique allows not only to obtain 3D topographic views and structural details, but also to measure the bacterialsurface interaction forces from biofilms. Compared with SEM, AFM offers a spatial resolution of 1-10 nm (Müller \& Engel, 2007).

Optical Coherence Tomography (OCT) is a methodology based on interference produced among light reflected and scattered from sample (biofilm) and reference light. It has been the first non-invasive methodology used for in situ visualization of biofilm with potential for its detection in the industry (Nguyen et al., 2012) and OCT could be digitalized to obtain a biofilm image (Wagner \& Horn, 2017). Another methodology, hyperspectral imaging technique, is based on the integration of spectral fluorescence signals obtained after UV-radiation of the sample and it has been used for E. coli O157:H7 and Salmonella biofilm detection on several surfaces (Jun et al., 2010). Based on this technology, handheld hyperspectral imaging systems that detect florescence at 3 wavelengths have been used to monitor surface sanitization in the industry (Wiederoder, Liu, Lefcourt, Kim, \& Martin, 2013).

Different commercial products exist to detect biofilms in open surfaces and they are an effective tool for hygiene monitoring. For example, BioFinder (Itram Higiene ${ }^{\circledR}$ ), TBF $^{\circledR} 300$ and TBF $^{\circledR} 300$ S are specialized products for the detection of biofilm by simple visual inspection based on the selective dying of the biofilm exopolymeric matrix produced by different type of microorganisms. Thanks to its simple application and response type, handling by technical staffs is not required (Betelgeux, 2016; Itram Higiene, 2012).

\subsection{Genotypic identification of biofilm-producing strains}

The relative expression of genes involved on curli, fimbriae and cellulose production ( $c s g D, \operatorname{csgB}, a d r A$ and $b a p A)$ has permitted to detected biofilm formation by Salmonella on eggshells (Pande et al., 2016). However, expression of these gens and subsequent biofilm formation is influenced by growth media, indicating a strong dependence of environmental conditions on biofilm formation (Wang, Dong, Wang, $\mathrm{Xu}$, \& Zhou, 2016).

Other approaches have been proposed to evaluate viable cells, based on molecular techniques such as quantitative PCR (qPCR) (Yoshida et al., 2003). However, this methodology failed to discriminate subpopulations with different viability state or extra cellular DNA (eDNA) present on the biofilm matrix (Ben-Amor et al., 2005; Kruger et al., 2014). The propidium monoazide (PMA) is a propidium iodide (IP) derivative that binds to free DNA or to DNA from cells with a damaged membrane rendering their amplification by PCR technique not possible (Nocker, Cheung, \& Camper, 2006). The PMA used before DNA extraction has been utilized to evaluate viable cells on biofilm and avoids quantification of eDNA or DNA from non-viable cells (Yasunaga et al., 2013). The utilization of fluorescence-staining techniques, based on membrane permeability or metabolic activity, in combination with fluorescence-microscopy techniques allows not only to evaluate live/ dead cells, but also their distribution on biofilm matrix (Pan, Harper, Ricci-Nittel, Lux, \& Shi, 2010; Shapiro, 2008). Fluorescein diacetate (FDA), carboxy-fluorescein diacetate (CFDA) and calcein acetoxymethyl (AM) are non-fluorescents dyes capable of crossing the cellular membrane and modified by the esterase enzyme of metabolically active cells. The modification of substrates produces a green fluorescent dye, which accumulates inside the cells and is easily detected by fluorescence microscopy (Breeuwer et al., 1995). Syto9 is a green fluorgenic dye able to cross bacterial membranes of both alive and dead cells, and bind not only to intracellular DNA (Boulos, Prévost, Barbeau, Coallier, \& Desjardins, 1999), but also to free nucleic acids on the biofilm matrix. 
Staining of viable cells could be combined with propidium iodide, a red fluorgenic dye able to cross the damaged membrane of injured cells and intercalate into DNA (Sachidanandham, Gin, \& Poh, 2005).

\section{Strategies to prevent and control biofilm formation}

Because of Salmonella biofilms' resistance to disinfectants and antibiotics, it is important to evaluate and develop alternative strategies to prevent their formation. The best strategy to eradicate bacterial biofilms from food-related environments is to prevent their formation (Coughlan, Cotter, Hill, \& Alvarez-Ordóñez, 2016).The facility and equipment design, and the choice of the materials and coatings used in the industry are extremely important to prevent biofilm formation. This is because even adopting the most effective cleaning and sanitizing programs, it is not possible to compensate for problems caused by faulty equipment, which have inaccessible corners, cracks, crevices, valves, and joints, which are vulnerable points for biofilm accumulation (Chmielewski \& Frank, 2006). The use of well-designed equipment associated with the adoption of effective hygiene measures allows for the removal of unwanted materials from surfaces, including microorganisms, foreign materials, and residues of cleaning products (Dosti, GuzelSeydim, \& Greene, 2005; Simões, Simões, Machado, Pereira, \& Vieira, 2006).

Furthermore, it was demonstrated for $S$. ser. Typhimurium that is best to use an electro-polished surface for surfaces, which are routinely being cleaned. In contrast, for surfaces, which are not accessible to regular cleaning, it is logical to consider mechanically sanded surface. Careful selection of the material used for the surfaces of the production lines would improve product safety and quality, particularly when bacteria develop resistance to antimicrobials (Schlisselberg \& Yaron, 2013).

Once the biofilm is already established, mechanical action is one of the main measures for its elimination or controls (Maukonen et al., 2003), because the friction acts on the matrix disruption, exposing deeper layers and making the microorganisms more accessible. Generally, disinfectants do not penetrate the biofilm matrix after an inefficient cleaning procedure and, therefore, do not destroy all the biofilm cells (Simões et al., 2006), reaching only the outer layers. Therefore cleaning is the first step to improve the sanitation of equipment and facilities (Hayes \& Forsythe, 1998).

Although the use of high temperatures may reduce the need for application of mechanical forces, such as turbulence in the wash water (Maukonen et al., 2003), it was reported that treatments performed at high temperature did not increase the efficacy of biofilm removal (Marion-Ferey et al., 2003). In addition to the mechanical action, other measures must be taken to prevent and control microbial adhesion (Table 1). The eradication of biofilms could be achieved through the combined use of treatments with different spectra and modes of action (Bridier, Briandet, Thomas, \& Dubois-Brissonnet, 2011). With this objective, numerous processes have been evaluated, associating chemical, natural or physical treatments. For example, a combination of triclosan and quaternary ammonium salts or halogenated furanones, antibiotics/ disinfectants, and nano- and micro-emulsions has been able to inhibit Salmonella biofilm formation (Steenackers, Hermans, Vanderleyden, \& De Keersmaecker, 2012). Recently, Miladi et al. (2017) evaluated the antibacterial susceptibility and the biofilm eradication of nalidixic acid (NA) in combination with three natural compounds carvacrol (CAR), thymol (TH) and eugenol (EUG), against twelve $S$. ser. Typhimurium strains and showed an eradication of biofilm formed. On the other hand, physical treatments can also be employed in association with chemical disinfectants; low-intensity ultrasonic or sonic agitation enhances the action of chlorhexidine against biofilm bacteria (Shen et al., 2010) and a combination of ultraviolet light with chlorine dioxine was shown to be more effective in eradicating drinking water biofilms than the two treatments applied separately (Rand et al., 2007). An important point to be analyzed for the elimination of bacteria in mature biofilms is the involvement of strain-dependent characteristics, since there are molecular intrinsic factors that may act by preventing the effectiveness of the agents, hindering their penetration depending on the composition of the matrix, and also the mechanism of action of the applied agent (Rossi, Melo, Mendonça, \& Monteiro, 2017).

\subsection{Disinfectants}

Disinfectants must be effective, safe, and easy to handle. They should be easily removed from surfaces, using water, leaving no residue in the final product that may affect the consumer (Simões, Simões, \& Vieira, 2010a). The chemicals currently used in the disinfection processes belong to the following types: acidic compounds, biocides, aldehyde-based disinfectants, caustics, chlorine, hydrogen peroxide, iodine, isothiazolinones, ozone, peracetic acid, phenols, biguanides, and surfactants (Bremer, Fillery, \& McQuillan, 2006; Simões et al., 2006). Ziech et al. (2016) reported that treatment with peracetic acid was not considered efficient to eliminate biofilms formed in polypropylene and polyurethane. Recently, Sarjit and Dykes (2017) reported that trisodium phosphate was more effective against biofilms than sodium hypochlorite and has strong potential as a sanitizer to reduce biofilm formation by Salmonella spp. on abiotic surfaces during poultry processing. However, studies show that even using the recommended concentration of sanitizer, resistance of bacteria in biofilms still exists. One strategy to prevent the induction of bacterial adaptation to disinfectants within biofilm structures could be to substantially increase the concentration of the antimicrobial agent. However, this approach might not guarantee biofilm eradication and it would be costly and not environmentally-friendly.

Several studies have been performed to compare the susceptibility between biofilm and planktonic Salmonella cells against chemical disinfectants. Salmonella biofilms on plastic, cement and stainless steel surfaces are much more resistant to the sanitizers chlorine and iodine as compared to planktonic cells (Joseph, Otta, Karunasagar, \& Karunasagar, 2001). Exposure to a solution of $100 \mathrm{ppm}$ chlorine or $50 \mathrm{ppm}$ iodine for at the least $15 \mathrm{~min}$ (depending on the surface) is needed to completely remove the biofilms, while planktonic cells are completely killed after exposure to a solution of $10 \mathrm{ppm}$ of chlorine or

Table 1

Overview of current and prospective anti-biofilm strategy.

(Koo, Allan, Howlin, Stoodley, \& Hall-Stoodley, 2017 modified).

\begin{tabular}{|c|c|c|c|}
\hline Types & Biofilm component & Biofilm phase & Examples \\
\hline Disinfectants & Microbial cell & All stages & Hydrogen peroxide, iodine, isothiazolinones, ozone, peracetic acid, phenols \\
\hline Antibiotics & Microbial cell & All stages & Enrofloxacin, ampicillin and ciprofloxacin \\
\hline Natural antimicrobials & Microbial cell, EPS & All stages & Carvacrol, casbane and diterpene \\
\hline Enzymes & EPS & Early/mature biofilm & Cellulase, lipase \\
\hline Quorum sensing inhibitors & Microbial cell & All stages & Brominated furanones and acylhomoserine lactones (AHLs) \\
\hline Nanoparticles & Microbial cell, EPS & All stages & Zinc oxide, poly (DL-lactide-co-glycolide) (PLGA) \\
\hline Lactic acid bacteria & Microbial cell & Initial attachment, early biofilm & Lactobacillus plantarum, Lactobacillus rhamnosus \\
\hline Bacteriophages & Microbial cell & Early/mature biofilm & Phage P22 \\
\hline
\end{tabular}


iodine for 10 or $5 \mathrm{~min}$, respectively. These results have been corroborated by Møretrø et al. (2009), who found that disinfectants based on hypochlorite (approximately $400 \mathrm{ppm}$ ), glutaraldehyde and cationic tensides (alkylamino acetate, didecylmethylammonium chloride and benzalkonium chloride) did not show a sufficient effect on Salmonella biofilms on stainless steel surfaces at the recommended user concentrations after $5 \mathrm{~min}$ of exposure, while they were effective against Salmonella in suspension. However, exposure to acidic peroxygen-based disinfectants and a product containing $70 \%$ ethanol was found to eliminate the biofilms after $5 \mathrm{~min}$. Wong et al. (2010) described that Salmonella biofilms on polystyrene pegs are also less susceptible to the disinfectants chlorhexidine gluconate, citric acid, benzalkonium chloride and other quaternary ammonium compounds, compared to planktonic cells. However, sodium hypochlorite was found to completely eradicate biofilms on polystyrene pegs after $1 \mathrm{~min}$ of exposure at concentration of approximately $1300 \mathrm{ppm}$, whereas $70 \%$ ethanol failed to eliminate the biofilms after 5 min of exposure. Ramesh, Joseph, Carr, Douglass, and Wheaton (2002) concluded, from a comparative study of the effect of different classes of disinfectants (sodium hypochlorite, sodium chlorite, quaternary ammonium, iodine, enzymes, and phenol) on Salmonella biofilms in galvanized steel surfaces, that a hypochlorite based disinfectant with a sodium hypochlorite concentration of $500 \mathrm{ppm}$ was the most effective biofilm inhibitor.

Several studies have been performed in order to unravel the mechanistic basis of the increased resistance of Salmonella to disinfectants in biofilms as compared to planktonic cells. Solano et al. (2002) compared the influence of $30 \mathrm{ppm}$ of sodium hypochlorite on the survival of biofilms of wild-type $S$. ser. Enteritidis and cellulose mutants formed on glass. The $75 \%$ of the wild-type cells survived a 20 min exposure to the disinfectant, while only $0.3 \%$ of the cellulose-deficient mutant cells survived, which clearly indicates the protective function of cellulose. Furthermore, Scher, Römling, \& Yaron, 2005 reported an enhanced resistance to hypochlorite of pellicle forming $S$. ser. Typhimurium cells as compared to a $b \operatorname{cs} A \operatorname{csg} B A$ double mutant. Cellulose and curli also seem to play a role in the protection of these bacteria on parsley against chlorination. Other mechanisms such as the ability to penetrate the plant tissue or preexisting biofilms and the production of different polysaccharides other than cellulose, possibly also provide and/or enhance protection against this treatment (Lapidot, Römling, \& Yaron, 2006; Lapidot \& Yaron, 2009). These results were further corroborated by White et al. (2006), who investigated the influence of $60 \mathrm{ppm}$ of sodium chlorite on stationary phase planktonic cells and $S$. ser. Typhimurium rdar colonies that had been stored for 3 months on plastic.

Dried colonies of wild-type $S$. ser. Typhimurium and a curli deficient csgA mutant strain were found to be highly resistant (less than 1-log reduction after treatment) as compared to planktonic cells (6-log reduction), while mucoid colonies of the cellulose deficient $b c s A$ strain were found to be susceptible (4-log reduction). Remarkably, csgD colonies were even more susceptible (6-log reduction), indicating that next to cellulose, additional components regulated by $\operatorname{CsgD}$, other than curli, confer protection against sodium hypochlorite. The finding of Stocki et al. (2007) that CsgD also mediates resistance of dried rdar colonies to a peroxygen based disinfectant, a quaternary ammonium sanitizer and chlorophenol, indicates that protection by CsgD regulated matrix components appears to be a general resistance mechanism.

Consistent results were found by Tabak et al. (2007), who studied the effect of the disinfectant triclosan on planktonic Salmonella (log and stationary phases), on biofilm-associated cells and on bacteria derived from disrupted biofilms. While a strong effect of triclosan $(1000 \mu \mathrm{g} / \mathrm{mL})$ on log phase cells was observed, a smaller and identical effect was found on stationary phase and biofilm derived cells, and only a weak effect was found on biofilm-associated cells. The higher resistance of biofilm-associated cells as compared to biofilm-derived cells suggests that the matrix also plays a significant role in the resistance against triclosan. This was corroborated by the finding that deletions in the genes coding for curli and cellulose synthesis makes the biofilm more susceptible. Furthermore, resistance to triclosan was attributed to a biofilm-specific adaptive response which was obtained by an enhanced expression of $a c r A B$ (encoding an efflux pump) and marA (activator of $a c r A B$ ), resulting in an increased efflux of triclosan and the cellulose synthesis genes $b c s A$ and $b c s E$, resulting in enhanced EPS production.

Several studies found that adaptive resistance also plays a role in the resistance of Salmonella biofilms against benzalkonium chloride (Mangalappalli-Illathu \& Korber, 2006; Mangalappalli-Illathu, Vidovic, \& Korber, 2008). Indeed, biofilms adapted to benzalkonium chloride, by exposure to subinhibitory concentrations over a certain time period, acquired the ability to survive a normally lethal exposure of this disinfectant and then resume growth. Adaptation occurred concurrently with the up-regulation of key proteins involved in the cold shock response, stress response, detoxification and an overall increase in protein biosynthesis, explaining the mechanisms responsible for adaptive resistance (Steenackers et al., 2012).

\subsection{Antibiotics}

Salmonella biofilms also confer resistance to antibiotics. Olson, Ceri, Morck, Buret, and Read (2002) compared the effect of the antibiotics enrofloxacin, gentamicin, erythromycin, tilmicosin, ampicillin, oxytetracycline and trimethoprim-sulfadoxine on planktonic cells and on preestablished biofilms on polystyrene pegs of clinical Salmonella ser. Typhimurium and Salmonella ser. Bredeney isolates. Planktonic populations were found to be sensitive (Minimal Inhibitory Concentration-MIC- ${ }^{<} 20 \mu \mathrm{g} / \mathrm{mL}$ for at least 1 of the isolates) to all antibiotics except for erythromycin and tilmicosin, whereas Salmonella biofilms are only sensitive to enrofloxacin and ampicillin ( $S$. ser. Bredeney only). Furthermore, Tabak, Scher, Chikindas, and Yaron (2009) reported that $S$. ser. Typhimurium biofilms pre-formed on microplates are up to a 2000 -fold more resistant to ciprofloxacin as compared to planktonic cells. This is particularly concerning as ciprofloxacin, together with third generation cephalosporins, such as ceftriaxone and cefotaxime, is commonly used to treat non-typhoid Salmonella infections (Parry \& Threlfall, 2008). In a different setup, Majtan, Majtánová, Xu, and Majtán (2008) tested the effect of subinhibitory concentrations of gentamicin, ciprofloxacin and cefotaxime on the amount of biofilm formed on polystyrene microtiter plates by clinical Salmonella isolates. While sub-MICs of gentamicin and ciprofloxacin reduced the amount of biofilm formed by all isolates tested, a significant increase in biofilm formation and EPS production was observed by cefotaxime at $1 / 2$ MIC in three isolates. These results support the notion that antibiotics are not only bacterial weapons for fighting competitors, but also signaling molecules that may regulate microbial communities (Linares, Gustafsson, Baquero, \& Martinez, 2006).

On the other hand, Papavasileiou et al. (2010) investigated 194 S. enterica strains, isolated from infected children, for their ability to form biofilms on silicone disks and compared the biofilms of the isolated strains to their corresponding planktonic forms with respect to susceptibility to 9 antimicrobial agents. About $56 \%$ of the strains were able to form biofilms. The biofilms showed increased antimicrobial resistance to all antibiotics as compared to the planktonic bacteria, with the highest resistance rates for gentamicin (90\%) and ampicillin (84\%).

\subsection{Natural antimicrobials}

The emergence of studies on the use of natural antimicrobials as anti-biofilm compounds has been seen in recent years. Plants make over 100,000 small-molecule compounds, many if not most of which have antimicrobial activity (Lewis \& Ausubel, 2006). Some compounds extracted from aromatic plants, which are natural and generally recognized as safe (GRAS), have demonstrated their antimicrobial activity on planktonic bacteria. Some of them are now being evaluated for their potential to eradicate biofilms. Examples include carvacrol, a natural terpene extracted from thyme or oregano (Knowles, Roller, Murray, \& 
Naidu, 2005), casbane diterpene, isolated from the ethanolic extract of Croton nepetaefolius, a Brazilian native plant (Carneiro et al., 2011), thymoquinone, an active principle of Arabian Nigella sativa seed (Chaieb, Kouidhi, Jrah, Mahdouani, \& Bakhrouf, 2011), and a naphthalene derivative isolated from Trachyspermum ammi seeds (Khan, Zakir, Khanam, Shakil, \& Khan, 2010), which limit the formation of biofilms of various bacterial species. Some of these compounds have been tested for their bactericidal activity on established biofilms. A promising method for the application of anti-biofilm essential oils is to vaporize these volatile compounds to enhance their access to the biological targets (Bridier et al., 2011). Valeriano et al. (2012) evaluated the anti-biofilm effect of disinfectant solutions formulated with peppermint (Mentha piperita) and lemongrass (Cymbopogon citratus) against biofilm formation by $S$. ser. Enteritidis S64, and found that after 20 and 40 min of treatment the biofilm was totally eliminated.

\subsection{Enzymes}

The use of enzymes may be useful to improve the cleaning process and are a viable option to overcome the biofilm problem in the food industry (Meireles, Borges, Giaouris, \& Simões, 2016). Enzymes can target cells in the biofilm matrix and can cause the matrix to become looser and break up. They can also trigger cell release actions in the biofilm enveloped cells, causing an amount of cells to break off from the biofilm. Enzymes have some role in targeting the bacterial cells encased within a biofilm, however the main function of enzymes is to degrade the lipid, carbohydrate and DNA components of the extracellular matrix, severing the links between cells and subsequently separating them, allowing rapid deterioration of the biofilm integrity (Coughlan et al., 2016). Nonetheless, limited studies have been carried out on Salmonella biofilm. Wang et al. (2016) studied the action of several surfactants and bio-enzymes individually and conjunctively to remove the Salmonella biofilm formed and showed that cetyltrimethyl ammonium bromide combined with cellulase drastically remove mature biofilm of Salmonella exposed to meat processing environments. However, due to the heterogeneity in biofilm matrices, it is necessary to know the precise composition at which suitable enzymatic treatments can be applied (Bridier et al., 2011), so that a mixture of different enzyme, can increase its action spectrum on biofilm degradation. These enzymatic processes have the advantage of disaggregating biofilm agglomerates, rather than just removing them from the surface, as in the case of mechanical action (Rossi et al., 2017).

The application of enzymes (alone or in combination with other compounds) for the control of bacterial biofilms in food environments provide an interesting alternative when the classical treatments involving chemical agents do not give satisfactory results in terms of hygiene.

\subsection{Quorum sensing inhibitors}

The discovery that many bacteria use quorum sensing (QS) circuits to develop biofilms makes it an attractive target for their control and have been proposed as promising antibiofilm agents (Brackman \& Coenye, 2015; Irie \& Parsek, 2008; Lazar, 2011). QS includes a densitydependent recognition of signaling molecules that results in the modulation of gene expression (Skandamis \& Nychas, 2012). Regulation of gene expression have been proposed as essential components of biofilm physiology (Parsek \& Greenberg, 2005) and some authors believed that quorum sensing inhibition may represent a natural, widespread, antibiofilm strategy (Simões, Simões, \& Vieira, 2010b). Several quorumsensing inhibitors, such as brominated furanones, have succeeded in interfering with biofilm formation (Ni, Li, Wang, \& Wang, 2009; Sintim, Al Smith, Wang, Nakayama, \& Yan, 2010). Chorianopoulos, Giaouris, Kourkoutas, and Nychas (2010) demonstrated that acyl homoserine lactones (AHLs), a molecule involved in the QS signal in Gram-negative bacteria, present in the cell-free supernatant of a Hafnia alvei culture had a negatively influence of the biofilm development by Salmonella enterica ser. Enteritidis on stainless steel. Interestingly, Dheilly et al. (2010) reported the inhibitory activity of supernatant from marine bacterium Pseudoalteromonas sp. strain 3J6 against biofilm formation on glass flow cells by three strains belonging to the human-pathogenic species Pseudomonas aeruginosa, S. ser. Enteritidis, and Escherichia coli. A deep understanding of the QS phenomenon in bacteria relevant to food processing may be used to control their biofilm formation through the identification of products that could affect QS and as thus biofilm formation (Lazar, 2011). However, it should be noted that the practical application of such products in real food processing environments may encounter non-manageable problems, such as the inability QS inhibitors to be effective against food relevant biofilms, which may incorporate a high amount of food residues and mineral components (Brackman \& Coenye, 2015).

\subsection{Nanoparticles}

Nanoparticles were proposed as an interventional strategy for the controlling biofilm formation due to versatility, temperature stability, low cost and their high surface area to volume ratio and unique chemical and physical properties (Liu et al., 2016; Pezzoni et al., 2017). For some time, these particles have been used to deliver drug compounds to targeted sites in the human body, and this technology could be applied to the food industry (Das, Ansari, Tripathi, Dwivedi, \& Premendra, 2011; Gangadoo, Stanley, Hughes, Moore, \& Chapman, 2016). Zinc oxide quantum dots ( $\mathrm{ZnO}$ nanoparticles) inhibit biofilm formation through the production of oxygen radicals, and can also be used to coat surfaces in the food manufacturing and packaging processes (Eshed, Lellouche, Matalon, Gedanken, \& Banin, 2012). ZnO nanoparticles are generally regarded as safe for consumption and inhibit the growth of $\mathrm{L}$. monocytogenes, Salmonella enteritidis, and E. coli O157:H7 (Jin, Sun, Su, Zhang, \& Sue, 2009; Tayel et al., 2011). Antibacterial activity of ZnO NP recommends its possible application as a potent sanitizing agent for disinfecting and sterilizing food industry equipment and containers against the attack and contamination with foodborne pathogenic bacteria (Tayel et al., 2011). Hill, Taylor, and Gomes (2013) used poly (DLlactide-co-glycolide) (PLGA) nanoparticles with encapsulated cinnamon bark extract (CBE) against $S$. ser. Typhimurium and L. monocytogenes. CBE contains antibacterial compounds (possibly QS inhibitors) and these nanoparticles effectively delivered CBE to the biofilm to inhibit its growth. Therefore, nanoencapsulation of chemical compounds could be a novel means of targeting biofilms in the food industry. Recently, Gkana, Doulgeraki, Chorianopoulos, and Nychas (2017) studied antibiofilm potential of commercial nanoparticle compounds based on organofunctionalized silanes and found to eliminate adherence of $S$. ser. Typhimurium and $E$. coli on modified glass surfaces, but this effect was not evident on stainless steel surfaces.

Nanoparticles appear as a current strategy for the removal of biomass of biofilms since they are stable at high temperature and pressures and can easily penetrate the matrix. However, more work is necessary for an effective application of nanomaterials under more realistic conditions of a poultry farm (Liu et al., 2016). Future research addressing cost, economics, and safety is likely to overcome many of the current limitations and create more opportunities for biofilm control by this technology.

\subsection{Lactic acid bacteria and bacteriocins}

In order to reduce Salmonella in poultry, some studies have investigated the use of lactic acid bacteria (LAB) and/or probiotic bacteria. Actually, probiotics were defined as living microorganisms that, when administered in adequate amounts, confer a health benefit to the host and many LAB are considered probiotics (Hill et al., 2014). The $\mathrm{LAB}$ are characterized by the production of lactic acid as a major catabolic end product from glucose. Lactic acid bacteria include various 
major genera: Lactobacillus, Lactococcus, Carnobacterium, Enterococcus, Lactosphaera, Leuconostoc, Melissococcus, Oenococcus, Pediococcus, Streptococcus, Tetragenococcus, Vagococcus and Weissella. Other genera are: Aerococcus Microbacterium, Propionibacterium and Bifidobacterium. Recent work has shown that certain LAB strains are able to reduce the formation of biofilms by Salmonella spp. (Chapman, Gibson, \& Rowland, 2014; Das et al., 2013; Gómez, Ramiro, Quecan, \& de Melo, 2016; Woo \& Ahn, 2013). This effect could be explained by its ability to coaggregate with potential pathogens and/or produce antimicrobial substances (such as hydrogen peroxide) and bio-surfactants that inhibit bacterial adhesion (Cadieux, Burton, Devillard, \& Reid, 2009). Das et al. (2013) reported that Lactobacillus plantarum strain KSBT 56, isolated from a traditional food product of India, effectively inhibited the growth, invasion and biofilm forming ability of Salmonella ser. Enteritidis.

Biofilm-forming LAB have been used as a strategy for the competitive exclusion of foodborne pathogens in food processing environments. Ait Ouali et al. (2014) showed that several biofilm forming LAB bacteria isolated from milk tanks functioned as a natural barrier or competitive exclusion organism in the food processing, including Salmonella among them. Gómez et al. (2016) reported that LAB strains could be excellent candidates to form protective biofilms formations for the control of $S$. ser. Typhimurium biofilm - forming through exclusion mechanisms. On the other hand, Petrova et al. (2016) reported that isolated lectin-like molecules from probiotic strain Lactobacillus rhamnosus GG possess a pronounced inhibitory activity against biofilm formation by various pathogens, including clinical Salmonella species.

The poultry industry has also investigated the use of bacteriocins and/or bacteriocin-producing bacteria for their ability to control Salmonella (Joerger, 2003; Vandeplas, Dubois Dauphin, Beckers, Thonart, \& Thewis, 2010). Bacteriocins are ribosomally synthesized antimicrobial peptides that are active against other bacteria, either of the same species (narrow spectrum), or across genera (broad spectrum) (Cotter, Hill, \& Ross, 2005). Bacteriocins may be produced by both gram negative and gram positive bacteria (Hassan, Kjos, Nes, Diep, \& Lotfipour, 2015). In recent years, bacteriocin producing LAB have attracted significant attention because of their GRAS status and potential use as safe additives for food preservation (De Vuyst \& Leroy, 2007). Nisin is an extracellular protein produced by some strains of Lactococcus lactis and has been employed as an antibiofilm agent (Bower, Daeschel, \& McGuire, 1998). More recently, Mahdavi, Jalali, and Kermanshahi (2007) demonstrated that nisin was mainly effective against of Salmonella ser. Enteritidis biofilm.

\subsection{Bacteriophages}

There is also renewed interest in controlling biofilms through the use of bacteriophages. Phages are viruses that infect and lyse bacteria and due to the emergency resistance to antibiotics, use of bacteriophage-derived tools as disinfectants is an important research field (Gutiérrez, Rodríguez-Rubio, Martínez, Rodríguez, \& García, 2016). Bacteriophages are currently considered an alternative adjunct to antibiotics for bacterial infections, especially for biofilm inhibition or disruption. These easily diffuse through the EPS (Briandet et al., 2008) and are active on established biofilms (Donlan, 2009). Moreover, many phages produce depolymerases that hydrolyze the extracellular polymers in a biofilm and trigger its disruption. The drawbacks of phages are their narrow host ranges, but phage mixtures or engineered phages could provide interesting solutions. Numerous studies have been reported on the biocontrol or elimination of Salmonella in poultry with phage. Andreatti Filho et al. (2007) have reported a decrease between 45 and $70 \%$ of $S$. ser. Enteritidis in previously infected chickens, compared with the untreated control. Atterbury et al. (2007) reported a decrease in the count of $S$. ser. Enteritidis and $S$. ser Typhimurium by 2 to 4 logs units compared to the untreated control. In contrast, there are many studies that demonstrate that phage treatment is almost null or null (Borie et al., 2008; Callaway et al., 2011; Capparelli et al., 2010; Gebru et al., 2010; Higgins et al., 2008; Hurley, Maurer, \& Lee, 2008; Johnson et al., 2008; Sillankorva et al., 2010; Vandeplas et al., 2010; Wall, Zhang, Rostagno, \& Ebner, 2010). Abedon (2015) proposed, through a microbial ecology approach, various aspects to consider for effective application of phages on biofilms. This includes the application moment, the use of phage mixtures and the environment where phages are employed. According to this author, other authors point out the need to optimize the conditions of application of the phages (Endersen et al., 2014; Pérez Pulido, Grande Burgos, Gálvez, \& Lucas López, 2016).

To date, few papers have focused on evaluating the effectiveness of phage on the formation of Salmonella biofilms. Karaca, Akcelik, and Akcelik (2015) showed that phage P22 can reduce the biofilm forming capacity of $S$. ser. Typhimurium, significantly at early stages and to a lesser extent in mature biofilms. Recently, Gong and Jiang (2017) demonstrated that bacteriophages were effective on reducing Salmonella attachment and biofilms formation on hard surfaces under both laboratory and greenhouse conditions. Furthermore, Garcia et al. (2017) reported the efficacy of a bacteriophage pool to control established Salmonella biofilm on surfaces present in chicken slaughterhouses.

\subsection{Others}

The surfactants and biosurfactants are also alternatives that can be used in combating biofilm formation. The surfactants are compounds that lower the surface tension between liquids and solids. In order for surfactants to be effective in removing biofilms, they would have to penetrate into the interface between the solid substrate and the biofilm so they could adsorb at the interface and reduce the interfacial tension. Consequently, the attractive interactions between the bacterial surfaces and the solid surface may be decreased, which would ease lead to the removal of the film (McLandsborough, Rodriguez, Perez-Conesa, \& Weiss, 2006). Some biofilm bacteria produce their own surfactants in order to disperse from a surface. The surfactin is a cyclic heptapeptide that is considered an anionic surfactant due to aspartic and glutamic acid residues that are negatively charged at neutral $\mathrm{pH}$ (Shen, Lin, Thomas, Taylor, \& Penfold, 2011). Rhamnolipids are also anionic surfactants owing to the presence of carboxyl and rhamnosyl groups (Ishigami, Gama, Ishii, \& Choi, 1993). Rhamnolipids and surfactin were able to control the attachment and to disrupt biofilms of individual and mixed cultures of Staphylococcus aureus, Listeria monocytogenes and $S$. ser. Enteritidis (Gomes \& Nitschke, 2012).

On the other hand, Salmonella regulates expression of many virulence- and biofilm-related processes using kinase-driven pathways (Latasa et al., 2012). Recently, Koopman et al. (2015) used small molecule adenosine mimetics [3-(2-furylmethyl)-2-[[(5-hydroxy-1 $H$-pyrazol-3-yl)methyl]thio]-3,5,6,7-tetrahydro-4H-cyclopenta[4,5] thieno [2,3-]pyrimidin-4-on], which was not bactericidal or bacteriostatic toward $S$. ser. Typhimurium or cytotoxic to mammalian cells, to decrease biofilm formation produced by $S$. ser. Typhimurium and $S$. ser. Typhi. The identification of a lead compound with biofilm-inhibiting capabilities toward Salmonella provides a potential new avenue of therapeutic intervention against Salmonella biofilm formation, with applicability to biofilms of other bacterial pathogens.

\section{Final considerations}

Salmonella is a major pathogen commonly associated with foodborne diseases and it is mainly related to the poultry industry. Contamination with these bacteria in poultry meat/eggs and poultry products can occur at multiple stages through the food chain, which include production, processing, distribution, retail marketing, handling and preparation. Salmonella spp. is able to adhere and form biofilms and this action constitutes a direct link between contamination in food processing environments and contamination of food products. 
Numerous methodologies based on different approximations have been developed for the phenotypic and genotypic detection and analysis of biofilm formation by microorganisms. These techniques aim to evaluate viability (quantification of viable cells), components of extra polymeric matrix (specific detection of extra polymeric substances, EPS) or biomass (evaluation of EPS and bacteria, both alive and dead).

It is necessary to develop a control strategy to reduce the impact of biofilm formation by Salmonella spp. on public health and avian production. Different commercial products exist to detect biofilms in open surfaces and they are an effective tool for hygiene monitoring. Once the biofilm is already established, emphasis should be put on the use of cleaning processes using mechanical action, which are one of the most effective measures for their control or elimination, because the friction produces the matrix disruption, exposing deeper layers and making the microorganisms more accessible. Researches about alternatives compounds, which may be used as a routine procedure for replacement of chemical sanitizers in the poultry industry in the future to combat biofilms, should be continued. Nanotechnology has emerged up as a new promising technology and an alternative to antibiotics to control Salmonella biofilm.

\section{Acknowledgments}

This work was supported by the Argentinean Agency for the Promotion of Science and Technology (Projects PID/2014/0049), Argentinean National Research Council (CONICET, PIP 0636), National Institute of Agricultural Technology (Specific Project 1130042), Ministry of Science, Technology and Productive Innovation, Argentina (PICTO-2009-0214 ANPCyT UNER -INTA-CAFESG), and CYTED Program (Network 115 RT0488). M.G, D.B and F.T. are members of the research career from the Argentinean National Research Council (CONICET).

\section{References}

Abedon, S. (2015). Ecology of anti-biofilm agents II: Bacteriophage exploitation and biocontrol of biofilm bacteria. Pharmaceuticals, 8, 559-589.

Ahmed, S., Gogal, R., \& Walsh, J. (1994). A new rapid and simple nonradioactive assay to monitor and determine the proliferation of lymphocytes: An alternative to [3H]thymidine incorporation assays. Journal of Immunology Method, 170, 211-224.

Ait Ouali, F., Al Kassaa, I., Cudennec, B., Abdallah, M., Bendali, F., Sadoun, D., ... Drider, D. (2014). Identification of lactobacilli with inhibitory effect on biofilm formation by pathogenic bacteria on stainless steel surfaces. International Journal of Food Microbiology, 191, 116-124.

Andreatti Filho, R. L., Higgins, J. P., Higgins, S. E., Gaona, G., Wolfenden, A. D., Tellez, G., \& Hargis, B. M. (2007). Ability of bacteriophages isolated from different sources to reduce Salmonella enterica serovar enteritidis in vitro and in vivo. Poultry Science, 86(9), 1904-1909.

Anonymous (2008). The increasing challenge of biofilms. International Food Hygiene, 18, $11-12$.

Atterbury, R. J., Van Bergen, M. A. P., Ortiz, F., Lovell, M. A., Harris, J. A., De Boer, A., ... Barrow, P. A. (2007). Bacteriophage therapy to reduce Salmonella colonization of broiler chickens. Applied and Environmental Microbiology, 73(14), 4543-4549.

Azeredo, J., Azevedo, N., Briandet, R., Cerca, N., Coenye, T., Costa, A., ... Sternberg, C. (2017). Critical review on biofilm methods. Critrical Reviews in Microbiology, 43, 313-351.

Ben-Amor, K., Heilig, H., Smidt, H., Vaughan, E., Abee, T., \& de Vos, W. (2005). Genetic diversity of viable, injured, and dead fecal bacteria assessed by fluorescence-activated cells or tingand 16SrRNA gene analysis. Applied and Environmental Microbiology, 71, 4679-4689.

Betelgeux (2016). How to detect biofilms? http://biofilmtest.com/how-to-detectbiofilms/?lang =en/, Accessed date: 9 July 2017.

Borie, C., Albala, I., Sanchez, P., Sanchez, M. L., Ramirez, S., Navarro, C., ... Robeson, J. (2008). Bacteriophage treatment reduces Salmonella colonization of infected chickens. Avian Diseases, 52(1), 64-67.

Boulos, L., Prévost, M., Barbeau, B., Coallier, J., \& Desjardins, R. (1999). LIVE/DEAD BacLight: Application of a new rapid staining method for direct enumeration of viable and total bacteria in drinking water. Journal of Immunology Method, 37, 77-86.

Bower, C., Daeschel, M., \& McGuire, J. (1998). Protein antimicrobial barriers to bacterial adhesion. Journal of Dairy Science, 81, 2771-2778.

Brackman, G., \& Coenye, T. (2015). Quorum sensing inhibitors as anti-biofilm agents. Current Pharmaceutical Design, 21(1), 5-11.

Breeuwer, P., Drocourt, J., Bunschoten, N., Zwietering, M., Rombouts, F., \& Abee, T. (1995). Characterization of uptake and hydrolysis of fluorescein diacetate and carboxyfluorescein diacetate by intracellular esterases in Saccharomyces cerevisiae, which result in accumulation of fluorescent product. Applied and Environmental Microbiology, $61,1614-1619$.

Bremer, P., Fillery, S., \& McQuillan, A. (2006). Laboratory scale clean-in-place (CIP) studies on the effectiveness of different caustic and acid wash steps on the removal of dairy biofilms. International Journal of Food Microbiology, 106, 254-262.

Briandet, R., Lacroix-Gueu, P., Renault, M., Lecart, S., Meylheuc, T., Bidnenko, E. Fontaine-Aupart, M. (2008). Fluorescence correlation spectroscopy to study diffusion and reaction of bacteriophages inside biofilms. Applied and Environmental Microbiology, 74, 2135-2143.

Bridier, A., Briandet, R., Thomas, V., \& Dubois-Brissonnet, F. (2011). Resistance of bacterial biofilms to disinfectants: A review. Biofouling, 27, 1017-1032.

Bridier, A., Dubois-Brissonnet, F., Boubetra, A., Thomas, V., \& Briandet, R. (2010). The biofilm architecture of sixty opportunistic pathogens deciphered using a high throughput CLSM method. Journal of Microbiological Methods, 82, 64-70.

Cadieux, P., Burton, J., Devillard, E., \& Reid, G. (2009). Lactobacillus by-products inhibit the growth and virulence of uropathogenic Escherichia coli. Journal of Physiology and Pharmacology, 60, 13-18.

Callaway, T. R., Edrington, T. S., Brabban, A., Kutter, B., Karriker, L., Stahl, C., ... Nisbet, D. J. (2011). Evaluation of phage treatment as a strategy to reduce Salmonella populations in growing swine. Foodborne Pathogens and Disease, 8(2), 261-266.

Capparelli, R., Nocerino, N., Iannaccone, M., Ercolini, D., Parlato, M., Chiara, M., \& Iannelli, D. (2010). Bacteriophage therapy of Salmonella enterica: A fresh appraisal of bacteriophage therapy. The Journal of Infectious Diseases, 201(1), 52-61.

Carneiro, V., dos Santos, H., Arruda, F., Bandeira, P., Albuquerque, M., Pereira, M., .. Teixeira, E. (2011). Casbane diterpene as a promising natural antimicrobial agent against biofilm associated infections. Molecules, 16, 190-201.

Chaieb, K., Kouidhi, B., Jrah, H., Mahdouani, K., \& Bakhrouf, A. (2011). Antibacterial activity of thymoquinone, an active principle of Nigella sativa and its potency to prevent bacterial biofilm formation. BMC Complementary and Alternative Medicine, 11(1), 29.

Chapman, C., Gibson, G., \& Rowland, I. (2014). Effects of single- and multi-strain probiotics on biofilm formation and in vitro adhesion to bladder cells by urinary tract. Anaerobe, 27, 71-76.

Chmielewski, R., \& Frank, J. (2006). A predictive model for heat inactivation of Listeria monocytogenes biofilm on rubber. Food Science and Technology, 39, 11-19.

Chorianopoulos, N. G., Giaouris, E. D., Kourkoutas, Y., \& Nychas, G.-J. (2010). Inhibition of the early stage of Salmonella enterica serovar Enteritidis biofilm development on stainless steel by cell-free supernatant of a Hafnia alvei culture. Applied and Environmental Microbiology, 76(6), 2018-2022.

Christensen, G., Simpson, W., Yonger, J., Baddor, L., Barrett, F., Melton, D., \& Beachey, E. (1985). Adherence of coagulase-negative staphylococci to plastic tissue culture plates: A quantitative model for the adherence of staphylococci to medical devices. Journal of Clinical Microbiology, 22, 996-1006.

Clayborn, J., Adams, J., Baker, C. A., \& Ricke, S. C. (2015). Assessment of Salmonella spp. attachment to reusable plastic containers based on scanning electron microscopy and BAX ${ }^{\circledR}$ PCR. Journal of Food Research, 4(2), 166.

Conway, A. (2016a). World poultry meat market growth modest in 2015-2016. Poultry Trends, 6-12.

Conway, A. (2016b). Egg production breaks record 70-million-metric-ton mark in 2015. Poultry Trends, 32-38.

Cotter, P. D., Hill, C., \& Ross, R. P. (2005). Bacteriocins: Developing innate immunity for food. Nature Reviews Microbiology, 3(10), 777-788.

Coughlan, L. M., Cotter, P. D., Hill, C., \& Alvarez-Ordóñez, A. (2016). New weapons to fight old enemies: Novel strategies for the (bio) control of bacterial biofilms in the food industry. Frontiers in Microbiology, 18(7), 1641.

Das, J., Mishra, D., Ray, P., Tripathy, P., Beuria, T., Singh, N., \& Suar, M. (2013). In vitro evaluation of anti-infective activity of a Lactobacillus plantarum strain against Salmonella enterica serovar enteritidis. Gut Pathogens, 5, 1-11.

Das, M., Ansari, K. M., Tripathi, A., Dwivedi, P. D., \& Premendra, D. (2011). Need for safety of nanoparticles used in food industry. Journal of Biomedical Nanotechnology, $7(1), 13-14$.

Davies, R., \& Breslin, M. (2003). Observations on Salmonella contamination of commercial laying farms before and after cleaning and disinfection. Veterinary Record, 152, 283-287.

De Oliveira, D., Fernandes Júnior, A., Kaneno, R., Silva, M., Araújo Júnior, J., Silva, N., \& Rall, V. (2014). Ability of Salmonella spp. to produce biofilm is dependent on temperature and surface material. Foodborne Pathogens and Disease, 11, 478-483.

De Vuyst, L., \& Leroy, F. (2007). Bacteriocins from lactic acid bacteria: Production, purification, and food applications. Journal of Molecular Microbiology and Biotechnology, 13(4), 194-199.

Dheilly, A., Soum-Soutéra, E., Klein, G. L., Bazire, A., Compère, C., Haras, D., \& Dufour, A. (2010). Antibiofilm activity of the marine bacterium Pseudoalteromonas sp. strain 3J6. Applied and Environmental Microbiology, 76(11), 3452-3461.

Dominiak, D. M., Nielsen, J. L., \& Nielsen, P. H. (2011). Extracellular DNA is abundant and important for microcolony strength in mixed microbial biofilms. Environmental Microbiology, 13(3), 710-721.

Donlan, R., \& Costerton, J. (2002). Biofilms: Survival mechanisms of clinically relevant microorganisms. Clinical Microbiology Reviews, 15, 167-193.

Donlan, R. M. (2002). Biofilms: Microbial life on surfaces. Emerging Infectious Diseases, 8, $881-890$.

Donlan, R. M. (2009). Preventing biofilms of clinically relevant organisms using bacteriophage. Trends in Microbiology, 17, 66-72.

Dookeran, M. M., Baccus-Taylor, G. S., Akingbala, J. O., Tameru, B., \& Lammerding, A. M. (2012). Transmission of Salmonella on broiler chickens and carcasses from production to retail in Trinidad and Tobago. Journal of Agriculture and Biodiversity Research, 1, 78-84. 
Dosti, B., Guzel-Seydim, Z., \& Greene, A. (2005). Effectiveness of ozone, heat and chlorine for destroying common food spoilage bacteria in synthetic media and biofilms. International Journal of Dairy Technology, 58, 19-24.

Duguid, J. P., Anderson, E. S., \& Campbell, I. (1966). Fimbriae and adhesive properties in Salmonellae. The Journal of Pathology and Bacteriology, 92, 107-138.

Endersen, L., O'Mahony, J., Hill, C., Ross, R., McAuliffe, O., \& Coffey, A. (2014). Phage therapy in the food industry. Annual Review of Food Science and Technology, 5, 327-349.

Eshed, M., Lellouche, J., Matalon, S., Gedanken, A., \& Banin, E. (2012). Sonochemical coatings of $\mathrm{ZnO}$ and $\mathrm{CuO}$ nanoparticles inhibit Streptococcus mutans biofilm formation on teeth model. Langmuir, 28(33), 12288-12295.

Farrell, D. (2013). The role of poultry in human nutrition. Poultry development review (pp. 2-3). Food and Agriculture Organization of the United Nations.

Field, D., O'Connor, R., Cotter, P., Ross, R., \& Hill, C. (2016). In vitro activities of nisin and nisin derivatives alone and in combination with antibiotics against Staphylococcus biofilms. Frontiers in Microbiology, 7, 508-519.

Freeman, D. J., Falkiner, F. R., \& Keane, C. T. (1989). New method for detecting slime production by coagulase negative staphylococci. Journal of Clinical Pathology, 42(8), 872-874.

Gangadoo, S., Stanley, D., Hughes, R. J., Moore, R. J., \& Chapman, J. (2016). Nanoparticles in feed: Progress and prospects in poultry research. Trends in Food Science \& Technology, 58, 115-126.

Garcia, K. C. D. O. D., Corrêa, I. M. D. O., Pereira, L. Q., Silva, T. M., Mioni, M. D. S. R., Izidoro, A. C. D. M., ... Andreatti Filho, R. L. (2017). Bacteriophage use to control Salmonella biofilm on surfaces present in chicken slaughterhouses. Poultry Science, 96(9), 3392-3398. http://dx.doi.org/10.3382/ps/pex124.

Gast, R. (2008). Salmonella infection. In Y. Saif, A. Fadly, J. Glisson, L. McDougald, L. Nolan, \& D. Swayne (Eds.). Diseases of poultry (pp. 619). Ames: Iowa, Blakwell Publishing.

Gast, R. (2013). Paratyphoid infections. In D. E. Swayne (Ed.). Diseases of poultry (pp. 673-713). Ames Iowa: Wiley-Blackwell Publishing 718-733.

Gebru, E., Lee, J. S., Son, J. C., Yang, S. Y., Shin, S. A., Kim, B., ... Park, S. C. (2010). Effect of probiotic-, bacteriophage-, or organic acid-supplemented feeds or fermented soybean meal on the growth performance, acute-phase response, and bacterial shedding of grower pigs challenged with serotype Typhimurium. Journal of Animal Science, 88(12), 3880-3886.

Giaouris, E., Heir, E., Desvaux, M., Hébraud, M., Møretrø, T., Langsrud, S., ... Simões, M. (2015). Intra- and inter-species interactions within biofilms of important foodborne bacterial pathogens. Frontiers in Microbiology, 6, 841. http://dx.doi.org/10.3389/ fmicb.2015.00841.

Gkana, E. N., Doulgeraki, A. I., Chorianopoulos, N. G., \& Nychas, G. J. E. (2017). Antiadhesion and anti-biofilm potential of organosilane nanoparticles against foodborne pathogens. Frontiers in Microbiology, 8, 1295.

Gomes, M., \& Nitschke, M. (2012). Evaluation of rhamnolipid and surfactin to reduce the adhesion and remove biofilms of individual and mixed cultures of food pathogenic bacteria. Food Control, 25, 441-447.

Gómez, N., Ramiro, J., Quecan, B., \& de Melo, F. B. (2016). Use of potential probiotic lactic acid bacteria (LAB) biofilms for the control of Listeria monocytogenes, Salmonella Typhimurium, and Escherichia coli O157: H7 biofilms formation. Frontiers in Microbiology, 7, 863 .

Gómez-Suárez, C., Busscher, H., \& van der Mei, H. (2001). Analysis of bacterial detachment from substratum surfaces by the passage of air-liquid interfaces. Applied and Environmental Microbiology, 67, 2531-2537.

Gong, C., \& Jiang, X. (2017). Application of bacteriophages to reduce Salmonella attachment and biofilms on hard surfaces. Poultry Science, 96, 1838-1848.

Gutiérrez, D., Rodríguez-Rubio, L., Martínez, B., Rodríguez, A., \& García, P. (2016). Bacteriophages as weapons against bacterial biofilms in the food industry. Frontiers in Microbiology, 7, 825.

Hassan, M., Kjos, M., Nes, I. F., Diep, D. B., \& Lotfipour, F. (2015). Antimicrobial peptides from prokaryotes. Novel Antimicrobial Agents and Strategies (pp. 71-90).

Hayes, P. R., \& Forsythe, S. J. (1998). Food hygiene, microbiology and HACCP. Springer Science \& Business Media.

Higgins, J. P., Andreatti Filho, R. L., Higgins, S. E., Wolfenden, A. D., Téllez, G., \& Hargis, B. M. (2008). Evaluation of Salmonella-lytic properties of bacteriophages isolated from commercial broiler houses. Avian Diseases, 52(1), 139-142.

Hill, C., Guarner, F., Reid, G., Gibson, G., Merenstein, D., Pot, B., \& Calder, P. (2014). Expert consensus document: The International Scientific Association for Probiotics and Prebiotics consensus statement on the scope and appropriate use of the term probiotic. Nature Reviews. Gastroenterology \& Hepatology, 11, 506.

Hill, L. E., Taylor, T. M., \& Gomes, C. (2013). Antimicrobial efficacy of poly (DL-lactideco-glycolide)(PLGA) nanoparticles with entrapped cinnamon bark extract against listeria monocytogenes and Salmonella typhimurium. Journal of Food Science, 78(4).

Hu, D., Zhang, R., Zou, Y., Zhong, H., Zhang, E. S., Luo, X., ... Jiang, Y. (2017). The structure-activity relationship of pterostilbene against Candida albicans biofilms. Molecules, 22, 360-371.

Hurley, A., Maurer, J. J., \& Lee, M. D. (2008). Using bacteriophages to modulate Salmonella colonization of the chicken's gastrointestinal tract: Lessons learned from in silico and in vivo modeling. Avian Diseases, 52(4), 599-607.

Irie, Y., \& Parsek, M. R. (2008). Quorum sensing and microbial biofilms. Current Topics in Microbiology and Immunology, 322, 67-84.

Ishigami, Y., Gama, Y., Ishii, F., \& Choi, Y. K. (1993). Colloid chemical effect of polar head moieties of a rhamnolipid-type biosurfactant. Langmuir, 9(7), 1634-1636.

Itram Higiene (2012). BiôFinder. http://www.itramhigiene.com/catalogos/en/ ItramHygiene_Biofinder_EN.pdf, Accessed date: 9 July 2017.

Jin, T., Sun, D., Su, J. Y., Zhang, H., \& Sue, H. J. (2009). Antimicrobial efficacy of zinc oxide quantum dots against Listeria monocytogenes, Salmonella enteritidis, and
Escherichia coli 0157: H7. Journal of Food Science, 74(1).

Joerger, R. D. (2003). Alternatives to antibiotics: Bacteriocins, antimicrobial peptides and bacteriophages. Poultry Science, 82(4), 640-647.

Johnson, R. P., Gyles, C. L., Huff, W. E., Ojha, S., Huff, G. R., Rath, N. C., \& Donoghue, A. M. (2008). Bacteriophages for prophylaxis and therapy in cattle, poultry and pigs. Animal Health Research Reviews, 9(2), 201-215.

Joseph, B., Otta, S., Karunasagar, I., \& Karunasagar, I. (2001). Biofilm formation by Salmonella spp. on food contact surfaces and their sensitivity to sanitizers. International Journal of Food Microbiology, 64, 367-372.

Jun, W., Kim, M. S., Cho, B. K., Millner, P. D., Chao, K., \& Chan, D. E. (2010). Microbial biofilm detection on food contact surfaces by macro-scale fluorescence imaging. Journal of Food Engineering, 99(3), 314-322.

Karaca, B., Akcelik, N., \& Akcelik, M. (2013). Biofilm-producing abilities of Salmonelle strains isolated from Turkey. Biologia, 68(1), 1-10.

Karaca, B., Akcelik, N., \& Akcelik, M. (2015). Effects of P22 bacteriophage on Salmonella enterica subsp. enterica serovar Typhimurium DMC4 strain biofilm formation and eradication. Archives of Biological Sciences, 67, 1361-1367.

Khan, R., Zakir, M., Khanam, Z., Shakil, S., \& Khan, A. U. (2010). Novel compound from Trachyspermum ammi (Ajowan caraway) seeds with antibiofilm and antiadherence activities against Streptococcus mutans: A potential chemotherapeutic agent against dental caries. Journal of Applied Microbiology, 109, 2151-2159.

Knowles, J., Roller, S., Murray, D., \& Naidu, A. (2005). Antimicrobial action of carvacrol at different stages of dual-species biofilm development by Staphylococccus aureus and Salmonella enterica serovar Typhimurium. Applied and Environmental Microbiology, 71 797-803.

Koo, H., Allan, R. N., Howlin, R. P., Stoodley, P., \& Hall-Stoodley, L. (2017). Targeting microbial biofilms: Current and prospective therapeutic strategies. Nature Reviews Microbiology. http://dx.doi.org/10.1038/nrmicro.2017.99.

Koopman, J. A., Marshall, J. M., Bhatiya, A., Eguale, T., Kwiek, J. J., \& Gunn, J. S. (2015) Inhibition of Salmonella enterica biofilm formation using small-molecule adenosine mimetics. Antimicrobial Agents and Chemotherapy, 59(1), 76-84.

Kroupitski, Y., Golberg, D., Belausov, E., Pinto, R., Swartzberg, D., Granot, D., \& Sela, S. (2009). Internalization of Salmonella enterica in leaves is induced by light and involves chemotaxis and penetration through open stomata. Applied and Environmental Microbiology, 75, 6076-6086.

Kruger, N., Buhler, C., Iwobi, A., Huber, I., Ellerbroek, L., Appel, B., \& Stingl, K. (2014) "Limits of control"-crucial parameters for a reliable quantification of viable campylobacter by real-time PCR. PLoS One, 9, e88108.

Lapidot, A., Römling, U., \& Yaron, S. (2006). Biofilm formation and the survival of Salmonella Typhimurium on parsley. International Journal of Food Microbiology, 109, 229-233.

Lapidot, A., \& Yaron, S. (2009). Transfer of Salmonella enterica serovar Typhimurium from contaminated irrigation water to parsley is dependent on curli and cellulose, the biofilm matrix components. Journal of Food Protection, 72, 618-623.

Latasa, C., García, B., Echeverz, M., Toledo-Arana, A., Valle, J., Campoy, S., ... Lasa, (2012). Salmonella biofilm development depends on the phosphorylation status of RcsB. Journal of Bacteriology, 194(14), 3708-3722.

Lazar, V. (2011). Quorum sensing in biofilms - How to destroy the bacterial citadels or their cohesion/power? Anaerobe, 17(6), 280-285.

Lewis, K., \& Ausubel, F. (2006). Prospects for plant-derived antibacterials. Nature Biotechnology, 24, 1504-1507.

Linares, J., Gustafsson, I., Baquero, F., \& Martinez, J. (2006). Antibiotics as intermicrobial signaling agents instead of weapons. Proceedings of the National Academy of Sciences of the United States of America. 103. Proceedings of the National Academy of Sciences of the United States of America (pp. 19484-19489).

Liu, C., Guo, J., Yan, X., Tang, Y., Mazumder, A., Wu, S., \& Liang, Y. (2016). Antimicrobial nanomaterials against biofilms: An alternative strategy. Environmental Reviews, 25(2) (225-24).

Mahdavi, M., Jalali, M., \& Kermanshahi, R. (2007). The effect of nisin on biofilm forming foodborne bacteria using microtiter plate method. Research in Pharmaceutical Sciences, 2, 113-118.

Majtan, J., Majtánová, L', Xu, M., \& Majtán, V. (2008). In vitro effect of subinhibitory concentrations of antibiotics on biofilm formation by clinical strains of Salmonella enterica serovar Typhimurium isolated in Slovakia. Journal of Applied Microbiology, 104(5), 1294-1301.

Malcova, M., Hradecka, H., Karpiskova, R., \& Rychlik, I. (2008). Biofilm formation in field strains of Salmonella enterica serovar Typhimurium: Identification of a new colony morphology type and the role of SGI1 in biofilm formation. Veterinary Microbiology, 129(3), 360-366.

Mangalappalli-Illathu, A., \& Korber, D. (2006). Adaptive resistance and differential protein expression of Salmonella enterica serovar enteritidis biofilms exposed to benzalkonium chloride. Antimicrobial Agents and Chemotherapy, 50, 3588-3596.

Mangalappalli-Illathu, A., Vidovic, S., \& Korber, D. (2008). Differential adaptive response and survival of Salmonella enterica serovar enteritidis planktonic and biofilm cells exposed to benzalkonium chloride. Antimicrobial Agents and Chemotherapy, 52, 3669-3680.

Marin, C., Hernandez, A., \& Lainez, M. (2009). Biofilm development capacity of Salmonella strains isolated in poultry risk factors and their resistance against disinfectants. Poultry Science, 88, 424-431.

Marion-Ferey, K., Pasmore, M., Stoodley, P., Wilson, S., Husson, G. P., \& Costerton, J. W. (2003). Biofilm removal from silicone tubing: An assessment of the efficacy of dialysis machine decontamination procedures using an in vitro model. Journal of Hospital Infection, 53(1), 64-71.

Maukonen, J., Matto, J., Wirtanen, G., Raaska, L., Mattila-Sandholm, T., \& Saarela, M. (2003). Methodologies for the characterization of microbes in industrial environments: A review. Journal of Industrial Microbiology and Biotechnology, 30, 327-356. 
McLandsborough, L., Rodriguez, A., Perez-Conesa, D., \& Weiss, J. (2006). Biofilms: At the interface between biophysics and microbiology. Food Biophysics, 1(2), 94-114.

Meireles, A., Borges, A., Giaouris, E., \& Simões, M. (2016). The current knowledge on the application of anti-biofilm enzymes in the food industry. Food Research International, $86,140-146$.

Miladi, H., Zmantar, T., Kouidhi, B., Chaabouni, Y., Mahdouani, K., Bakhrouf, A., \& Chaieb, K. (2017). Use of carvacrol, thymol, and eugenol for biofilm eradication and resistance modifying susceptibility of Salmonella enterica serovar Typhimurium strains to nalidixic acid. Microbial Pathogenesis, 104, 56-63.

Møretrø, T., Vestby, L., Nesse, L., Storheim, S., Kotlarz, K., \& Langsrud, S. (2009), Evaluation of efficacy of disinfectants against Salmonella from the feed industry. Journal of Applied Microbiology, 106, 1005-1012.

Müller, D. J., \& Engel, A. (2007). Atomic force microscopy and spectroscopy of native membrane proteins. Nature Protocols, 2(9), 2191-2197.

Neu, T., \& Lawrence, J. (2014). Investigation of microbial biofilm structure by laser scanning microscopy. Advances in Biochemical Engineering/Biotechnology, 146, 1-51.

Nguyen, C., Jung, W., Kim, J., Chaney, E., Novak, M., Stewart, C., \& Boppart, S. (2012). Noninvasive in vivo optical detection of biofilm in the human middle ear. Proceedings of the National Academy of Sciences of the United States. 109. Proceedings of the National Academy of Sciences of the United States (pp. 9529-9534).

Ni, N., Li, M., Wang, J., \& Wang, B. (2009). Inhibitors and antagonists of bacterial quorum sensing. Medicinal Research Reviews, 29, 65-124.

Nocker, A., Cheung, C., \& Camper, A. (2006). Comparison of propidium monoazide with ethidium monoazide for differentiation of live vs. dead bacteria by selective removal of DNA from dead cells. Journal of Microbiological Methods, 67, 310-320.

Olson, M., Ceri, H., Morck, D., Buret, A., \& Read, R. (2002). Biofilm bacteria: Formation and comparative susceptibility to antibiotics. Canadian Journal of Veterinary Research, 66, 86-92.

Ozkan, A., Topal, A., Dana, A., Guler, M., \& Tekinay, A. (2016). Atomic force microscopy for the investigation of molecular and cellular behavior. Micron, 89, 60-76.

Pan, P., Harper, S., Ricci-Nittel, D., Lux, R., \& Shi, W. (2010). In-vitro evidence for efficiency of antimicrobial mouthrinses. Journal of Dental Research, 38, 16-20.

Pande, V., McWhorter, A., \& Chousalkar, K. (2016). Salmonella enterica isolates from layer farm environments are able to form biofilm on eggshell surfaces. Biofouling, 32, 699-710.

Papavasileiou, K., Papavasileiou, E., Tseleni-Kotsovili, A., Bersimis, S., Nicolaou, C., \& Ioannidis, A. (2010). Comparative antimicrobial susceptibility of biofilm versus planktonic forms of Salmonella enterica strains isolated from children with gastroenteritis. European Journal of Clinical Microbiology \& Infectious Diseases, 29 1401-1405.

Parry, C., \& Threlfall, E. (2008). Antimicrobial resistance in typhoidal and nontyphoidal Salmonellae. Current Opinion in Infectious Diseases, 21, 531-538.

Parsek, M. R., \& Greenberg, E. P. (2005). Sociomicrobiology: The connections between quorum sensing and biofilms. Trends in Microbiology, 13(1), 27-33.

Peeters, E., Nelis, H., \& Coenye, T. (2008). Comparison of multiple methods for quantification of microbial biofilms grown in microtiter plates. Journal of Microbiological Methods, 72, 157-165.

Peng, M., Salaheen, S., Almario, J. A., Tesfaye, B., Buchanan, R., \& Biswas, D. (2016). Prevalence and antibiotic resistance pattern of Salmonella serovars in integrated croplivestock farms and their products sold in local markets. Environmental Microbiology, 18(5), 1654-1665.

Pérez Pulido, R., Grande Burgos, M. J., Gálvez, A., \& Lucas López, R. (2016). Application of bacteriophages in post-harvest control of human pathogenic and food spoiling bacteria. Critical Reviews in Biotechnology, 36(5), 851-861.

Petrova, M., Imholz, N., Verhoeven, T., Balzarini, J., Van Damme, E., Schols, D., \& Lebeer, S. (2016). Lectin-like molecules of Lactobacillus rhamnosus GG inhibit pathogenic Escherichia coli and Salmonella biofilm formation. PLoS One, 11, e0161337.

Pezzoni, M., Catalano, P., Pizarro, R., Desimone, M., Soler-Illia, G., Bellino, M. \& Costa, C. (2017). Antibiofilm effect of supramolecularly templated mesoporous silica coatings. Materials Science and Engineering, 77, 1044-1049.

Pitts, B., Hamilton, M., Zelver, N., \& Stewart, P. (2003). A microtiter-plate screening method for biofilm disinfection and removal. Journal of Microbiological Methods, 54 , 269-276.

Ramesh, N., Joseph, S., Carr, L., Douglass, L., \& Wheaton, F. (2002). Evaluation of chemical disinfectants for the elimination of Salmonella biofilms from poultry transport containers. Poultry Science, 81, 904-910.

Rand, J., Hofmann, R., Alam, M., Chauret, C., Cantwell, R., Andrews, R., \& Gaynon, G. (2007). A field study evaluation for mitigating biofouling with chlorine dioxide or chlorine integrated with UV disinfection. Water Research, 41, 1939-1948.

Riss, T. L., Moravec, R. A., Niles, A. L., Duellman, S., Benink, H. A., Worzella, T. J., \& Minor, L. (2004). Cell viability assays. In G. S. Sittampalam, N. P. Coussens, K. Brimacombe, A. Grossman, \& M. Arkin, (Eds.). Assay guidance manual. USA: Eli Lilly \& Company and the National Center for Advancing Translational Sciences: Bethesda (MD).

Roehm, N., Rodgers, G., Hatfield, S., \& Glasebrook, A. (1991). An improved colorimetric assay for cell proliferation and viability utilizing the tetrazolium salt XTT. Journal of Immunological Methods, 142, 257-265.

Rose, N., Beaudeau, F., Drouin, P., Toux, J., Rose, V., \& Colin, P. (2000). Risk factors for Salmonella persistence after cleansing and disinfection in French broiler-chicken houses. Preventive Veterinary Medicine, 44, 9-20.

Rossi, D., Melo, R., Mendonça, E., \& Monteiro, G. (2017). Biofilms of Salmonella and Campylobacter in the poultry industry. Poultry science (pp. 93-113). Intech.

Sachidanandham, R., Gin, K., \& Poh, C. (2005). Monitoring of active but non-culturable bacterial cells by flow cytometry. Biotechnology and Bioengineering, 89, 24-31.

Sarjit, A., \& Dykes, G. (2017). Antimicrobial activity of trisodium phosphate and sodium hypochlorite against Salmonella biofilms on abiotic surfaces with and without soiling with chicken juice. Food Control, 73, 1016-1022.

Scher, K., Römling, U., \& Yaron, S. (2005). Effect of heat, acidification, and chlorination on Salmonella enterica serovar Typhimurium cells in a biofilm formed at the air-liquid interface. Applied and Environmental Microbiology, 71, 1163-1168.

Schlisselberg, D. B., \& Yaron, S. (2013). The effects of stainless steel finish on Salmonella Typhimurium attachment, biofilm formation and sensitivity to chlorine. Food Microbiology, 35(1), 65-72.

Schonewille, E., Windhorst, D., \& Bräuni, I. (2012). Biofilm building properties of Salmonella on the poultry farm. International Poultry Production, 20, 13-15.

Shapiro, H. (2008). Flow cytometry of bacterial membrane potential and permeability. Methods in Molecular Medicine, 142, 175-186.

Sharma, V. K., \& Carlson, S. A. (2000). Simultaneous detection of Salmonella strains and Escherichia coli O157:H7 with fluorogenic PCR and single enrichment-broth culture. Applied and Environmental Microbiology, 66, 5472-5476.

Shen, H. H., Lin, T. W., Thomas, R. K., Taylor, D. J., \& Penfold, J. (2011). Surfactin structures at interfaces and in solution: The effect of $\mathrm{pH}$ and cations. The Journal of Physical Chemistry B, 115(15), 4427-4435.

Shen, Y., Stojicic, S., Qian, W., Olsen, I., \& Haapasalo, M. (2010). The synergistic antimicrobial effect by mechanical agitation and two chlorhexidine preparations on biofilm bacteria. Journal of Endodontics, 36, 100-104.

Sillankorva, S., Pleteneva, E., Shaburova, O., Santos, S., Carvalho, C., Azeredo, J., \& Krylov, V. (2010). Salmonella enteritidis bacteriophage candidates for phage therapy of poultry. Journal of Applied Microbiology, 108(4), 1175-1186.

Simões, L., Simões, M., \& Vieira, M. (2010a). Influence of the diversity of bacterial isolates from drinking water on resistance of biofilms to disinfection. Applied and Environmental Microbiology, 76, 6673-6679.

Simões, M., Simões, L., Machado, I., Pereira, M., \& Vieira, M. (2006). Control of flowgenerated biofilms using surfactants - Evidence of resistance and recovery. Food and Bioproducts Processing, 84, 338-345.

Simões, M., Simões, L. C., \& Vieira, M. J. (2010b). A review of current and emergent biofilm control strategies. LWT- Food Science and Technology, 43(4), 573-583.

Sintim, H., Al Smith, J., Wang, J., Nakayama, S., \& Yan, L. (2010). Paradigm shift in discovering next-generation anti-infective agents: Targeting quorum-sensing, c-diGMP signaling and biofilm formation in bacteria with small molecules. Future Medicinal Chemistry, 2, 1005-1035.

Skandamis, P. N., \& Nychas, G. J. (2012). Quorum sensing in the context of food microbiology. Applied and Environmental Microbiology, 78(16), 5473-5482.

Solano, C., Garcia, B., Valle, J., Berasain, C., Ghigo, J., \& Gamazo, C. (2002). Genetic analysis of Salmonella enteritidis biofilm formation: Critical role of cellulose. Molecular Microbiology, 43, 793-808.

Steenackers, H., Hermans, K., Vanderleyden, J., \& De Keersmaecker, S. (2012). Salmonell biofilms: An overview on occurrence, structure, regulation and eradication. Food Research International, 45, 502-531.

Stepanović, S., Vuković, D., Hola, V., Di Bonaventura, G., Djukić, S., Cirković, I., \& Ruzicka, F. (2007). Quantification of biofilm in microtiter plates: Overview of testing conditions and practical recommendations for assessment of biofilm production by staphylococci. APMIS, 115, 891-899.

Stocki, S., Annett, C., Sibley, C., McLaws, M., Checkley, S., \& Singh, N. (2007). Persistence of Salmonella on egg conveyor belts is dependent on the belt type but not on the rdar morphotype. Poultry Science, 86, 2375-2383.

Tabak, M., Scher, K., Chikindas, M., \& Yaron, S. (2009). The synergistic activity of triclosan and ciprofloxacin on biofilms of Salmonella Typhimurium. FEMS Microbiology Letters, 301, 69-76.

Tabak, M., Scher, K., Hartog, E., Römling, U., Matthews, K., \& Chikindas, M. (2007). Effect of triclosan on Salmonella Typhimurium at different growth stages and in biofilms. FEMS Microbiology Letters, 267, 200-206.

Tayel, A. A., El-Tras, W. F., Moussa, S., El-Baz, A. F., Mahrous, H., Salem, M. F., \& Brimer L. (2011). Antibacterial action of zinc oxide nanoparticles against foodborne pathogens. Journal of Food Safety, 31(2), 211-218.

Valeriano, C., De Oliveira, T. L. C., De Carvalho, S. M., das Graças Cardoso, M., Alves, E. \& Piccoli, R. H. (2012). The sanitizing action of essential oil-based solutions against Salmonella enterica serotype enteritidis S64 biofilm formation on AISI 304 stainless steel. Food Control, 25(2), 673-677.

Van den Driessche, F., Rigole, P., Brackman, G., \& Coenye, T. (2014). Optimization of resazurin-based viability staining for quantification of microbial biofilms. Journal of Microbiological Methods, 98, 31-34.

Vandeplas, S., Dubois Dauphin, R., Beckers, Y., Thonart, P., \& Thewis, A. (2010). Salmonella in chicken: Current and developing strategies to reduce contamination at farm level. Journal of Food Protection, 73, 774-785.

Velge, P., Cloeckeart, A., \& Barrow, P. (2005). Emergence of Salmonella epidemics: The problem related to Salmonella enterica serotype enteritidis and multiple antibiotic resistance in other major serotypes. Veterinary Research, 36, 267-288.

Wagner, M., \& Horn, H. (2017). Optical coherence tomography in biofilm research: A comprehensive review. Biotechnology and Bioengineering, 114, 1386-1402.

Wall, S. K., Zhang, J., Rostagno, M. H., \& Ebner, P. D. (2010). Phage therapy to reduce preprocessing Salmonella infections in market-weight swine. Applied and Environmental Microbiology, 76(1), 48-53.

Wang, H., Dong, Y., Wang, G., Xu, X., \& Zhou, G. (2016). Effect of growth media on gene expression levels in Salmonella Typhimurium biofilm formed on stainless steel surface. Food Control, 59, 546-552.

Wang, H., Wang, H., Xing, T., Wu, N., Xu, X., \& Zhou, G. (2016). Removal of Salmonella biofilm formed under meat processing environment by surfactant in combination with bio-enzyme. LWT-Food Science and Technology, 66, 298-304.

Wang, H., Ye, K., Wei, X., Cao, J., Xu, X., \& Zhou, G. (2013). Occurrence, antimicrobial resistance and biofilm formation of Salmonella isolates from a chicken slaughter plant in China. Food Control 33, 378-384. 
White, A., Gibson, D., Kim, W., Kay, W., \& Surette, M. (2006). Thin aggregative fimbriae and cellulose enhance long-term survival and persistence of Salmonella. Journal of Bacteriology, 188, 3219-3227.

Wiederoder, M., Liu, N., Lefcourt, A., Kim, M., \& Martin, L. Y. (2013). Use of a portable hyperspectral imaging system for monitoring the efficacy of sanitation procedures produce processing plants. Journal of Food Engineering, 117, 217-226.

Wong, H. S., Townsend, K. M., Fenwick, S. G., Maker, G., Trengove, R. D., \& O'Handley, R. M. (2010). Comparative susceptibility of Salmonella Typhimurium biofilms of different ages to disinfectants. Biofouling, 26(7), 859-864.

Woo, J., \& Ahn, J. (2013). Probiotic-mediated competition, exclusion and displacement in biofilm formation by food-borne pathogens. Letters in Applied Microbiology, 56, 307-313.

Xu, Z., Liang, Y., Lin, S., Chen, D., Li, B., Li, L., \& Deng, Y. (2016). Crystal violet and XTT assays on Staphylococcus aureus biofilm quantification. Current Microbiology, 73,
$474-482$.

Yasunaga, A., Yoshida, A, Morikawa, K, Maki, K., Nakamura, S., Soh, I, ... Ansai, T. (2013). Monitoring the prevalence of viable and dead cariogenic bacteria in oral specimens and in vitro biofilms by qPCR combined with propidium monoazide. BioMed Central Microbiology, 13, 157-166.

Yoshida, A., Suzuki, N., Nakano, Y., Kawada, M., Oho, T., \& Koga, T. (2003).

Development of a 5' nuclease-based real-time PCR assay for quantitative detection of cariogenic dental pathogens Streptococcus mutans and Streptococcus sobrinus. Journal of Clinical Microbiology, 41, 4438-4441.

Ziech, R., Perin, A., Lampugnani, C., Jagnow Seren, oM., Viana, C., Mendonça Soares, V., ... dos Santos Bersot, L. (2016). Biofilm-forming ability and tolerance to industrial sanitizers of Salmonella spp. Isolated from Brazilian Poultry Processing Plants. LWT Food Science and Technology, 68, 85-90. 